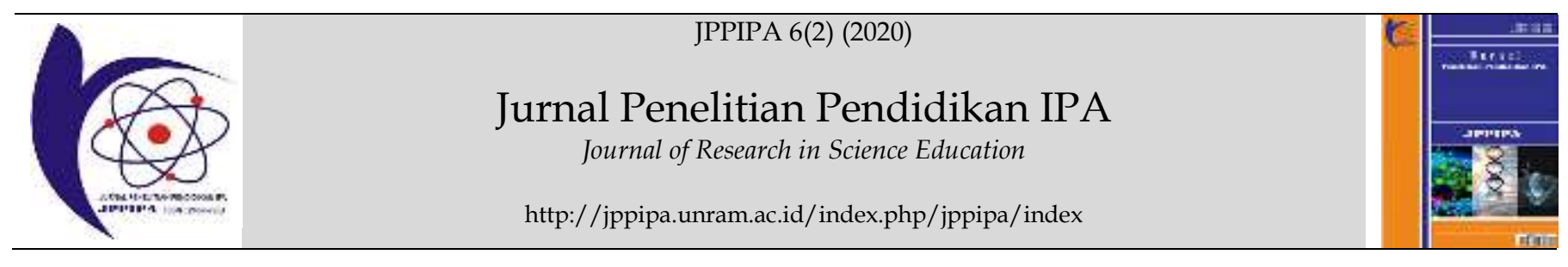

\title{
Approach to Representation of CRI Integrated Mathematics and Verbal (R-MV) to Analyze Misconception of Momentum and Impuls Materials
}

\author{
I Ketut Mahardika ${ }^{1 *}$, Zulfi Anggraini², Aris Doyan,4, I Wayan Sugiartana ${ }^{5}$ \\ ${ }^{1}$ Science Education Doctoral Study Program Faculty of Teacher Training and Education, University of Jember, Jember. Indonesia \\ 2 Physics Education Study Program, Faculty of Teacher Training and Education, University of Jember, Jember, Indonesia \\ ${ }^{3}$ Physics Education Study Program, Faculty of Teacher Training and Education, University of Mataram, Lombok, West Nusa Tenggara \\ Indonesia \\ ${ }^{4}$ Masters of Sciences Program, Postgraduate Program, University of Mataram, Lombok, West Nusa Tenggara, Indonesia \\ ${ }^{5}$ Junior high school 3 Tegallalang, Jalan Raya Kedisan, Bali, Indonesia
}

\section{DOI: $\underline{10.29303 / \text { ippipa.v6i2.437 }}$}

\section{Article Info}

Received : May 12th, 2020

Revised : June 30th, 2020

Accepted: July $27^{\text {th }}, 2020$

\begin{abstract}
Misconception is a misconception that refers to a concept that is not in accordance with scientific understanding or understanding received by experts in that field. This study aims to identify students' misconceptions in solving momentum and impulse problems through the R-MV approach (mathematical representation and verbal representation) integrated CRI (Certainly of Response Index). This research included in the type of qualitative descriptive analysis research. The subject of the research was tenthgrade students of Jember Regency Senior High School. Data collection techniques in this research use method of observation, tests, and interviews. The data analysis technique used was the mathematical representation approach integrated CRI. Based on the results of the research that has been done, the students' misconceptions percentage in Jember Senior High School of science tenth grade on material momentum and impulse through mathematical representation approach integrated CRI of $20.07 \%$ and through verbal representation approach integrated CRI of $32.94 \%$. This is included in the category (Almost Very Confident) for mathematical representation and (Sure) for verbal representation, meaning the value that students get as truthful based on understanding material with correct.
\end{abstract}

Keywords: Misconceptions; Momentum and Impulse; Mathematical Representation; Verbal Representation CRI.

Citation: Mahardika, I.K., Anggraini, Z., Doyan, A., \& Sugiarta, I.W. (2020). Approach to Representation of CRI Integrated Mathematics and Verbal (R-MV) to Analyze Misconception of Momentum and Impuls Materials. Jurnal Penelitian Pendidikan IPA (JPPIPA), 1(1), 232-237. doi: https:/ / doi.org/10.29303/jppipa.v6i2.437

\section{Introduction}

Physics is one branch of science and is a science that was born and developed through the steps of observation, formulation of problems, preparation of hypotheses, testing hypotheses through experiments, drawing conclusions, and finding theories and concepts (Trianto, 2013). In studying physics, the emphasis is on the understanding of a concept so that knowledge is formed through the activities of discovery, mathematical 
presentation of data, and certain other rules (Bektiarso, 2000).

Momentum and impulse material is one of the materials that are oriented in learning physics at school, namely the theories, formulas, concepts, and applications in everyday life. Momentum and impulses are material in physics that studies the behavior of an object's motion and the factors that influence the object's motion. Momentum is an important physics concept because it includes two things that characterize the dynamics of objects, namely mass, and speed. The concept of momentum and impulses at the high school level tends to teach a lot of formulas, but the concept is still very lacking. So consequently students will pay more attention to formulas than concepts or their nature (Hidayat, 2017).

In ideal circumstances, students should be able to master the material momentum and impulses with four kinds of multi-representation approaches, namely verbal representations, drawings, mathematics, and graphics. Students can understand the material provided in four kinds of multi-presentation approaches correctly. But there are still many students who experience problems in understanding the material with four kinds of multi-representation approaches so that students experience misconceptions. A misconception is a concept that refers to a concept that is not in accordance with scientific understanding or understanding received by experts in the field (Suparno, 2013).

Based on observations made in three Public Senior High Schools (PSHS) Pakusari, PSHS 4 Jember, and PSHS Balung in Jember District, it was found that learning in schools was student-centered, but did not rule out the possibility of teacher-centered conditionality certain.

In the three PSHS, there is the possibility of students experiencing misconceptions about the material momentum and impulses, this happens because all students have different thinking patterns, so it is very possible for misconceptions. Some students in the three PSHS still experience difficulties when working on problems related to verbal representations, drawings, and graphics, because most students prefer mathematical questions compared to questions about concepts. Some students think the problem with mathematical representation is very difficult because it deals with counting.

From the students' problems that have been explained above, an approach can be given to know students better understand the material momentum and impulses correctly, namely the multi-representation approach. The multi-representation approach can be used to analyze misconceptions in learning physics.
Representation is something that represents, describes, or symbolizes an object or process. Multirepresentation also means to re-represent the same concept with different formats, including verbal, pictures, graphics, and mathematics (Prain \& Waldrip, 2008). According to Mahardika (2016), the appearance of various representations in concept planting is predicted to be able to better help students understand the concepts being studied.

This is also related to the ability of each student who may have certain specific abilities. Of course, if the concept presentation is only emphasized in one representation, it will benefit a small number of students and not benefit the other students. For example, the concept presentation is only expressed in mathematical representation, so students who are more prominent in the ability of verbal or picture representation will find it difficult to understand the concepts presented, and so on.

In this study, only the R-MV approach (mathematical representation and verbal representation) is used to identify students' misconceptions on the material of momentum and impulses. As an amplifier to identify students' misconceptions, the R-MV approach (mathematical representation and verbal representation) is combined with an instrument to determine the level of student confidence that is Certainly of Response Index (CRI). CRI is a good instrument used to identify students' misconceptions while also being able to distinguish them by not knowing concepts because CRI has an index of student confidence that is included in each item.

CRI is usually based on a scale, which is called the CRI scale (0-5) (A'yun, et al. 2018). In this research, CRI acts as an amplifier to find out the students know the concepts, misconceptions, or do not know the concepts. If students are correct in answering questions with a multi-representation approach and the CRI scale that students choose $>2.5$ can be concluded that the student masters the concept well. If students are correct in answering questions with a multi-representation approach and the CRI scale that students choose $<2.5$ can be concluded that the student does not know the concept. If students are wrong in answering questions with a multi-representation approach and the CRI scale that students choose $>2.5$ can be concluded that the student is a misconception. If students are wrong in answering questions with a multi-representation approach and the CRI scale that students choose $<2.5$ can be concluded that the student does not know the concept.

So if the R-MV approach (mathematical representation and verbal representation) alone can only know the student misconceptions or understand concepts, but if given the reinforcement of the CRI can 
distinguish students who know the concept, misconception, or do not know the concept.

Based on this description, the researchers examined the level of the misconception of SHS Jember class $X$ students on the momentum and impulse material through the CR-integrated R-MV approach. In addition, the researchers also examined the causes of misconceptions experienced by Jember State High School students in class $\mathrm{X}$ on the material of momentum and impulses through the CR-integrated R-MV approach.

\section{Method}

This research was conducted in the even semester of the academic year 2017/2018. This type of research used in this research is descriptive qualitative analysis research. Qualitative descriptive research is a research method that aims to describe fully and deeply about social reality and various phenomena that occur in the community that is the subject of research so that they are described the characteristics, characters, traits, and models of these phenomena (Sanjaya, 2013). The research sites chosen by the researchers were SHS in
Jember District, namely PSHS 4 Jember, PSHS Pakusari, and PSHS Balung. The research subjects used by the researchers were PSHS students of class X IPA, from the three schools taken one class for research subjects.

Data collection techniques used in this study are using observation, tests, and interviews. The test instrument used in this study is an essay test that has been given an integrated CR-MV (mathematical and verbal representation) approach to identify students' misconceptions on the subject of momentum and impulse.

Analysis of the data used in this study is based on students' answers from the tests that have been given. The research data analysis techniques through several stages including:

First, look at students' answers to test questions that have been given an R-MV approach. Furthermore, researchers assess the answers of students who are right and wrong. Second, determine the value on the CRI scale used. The following are categories of students' level of confidence based on the CRI scale in Table 1. Next third, determine the level of student understanding based on the CRI to distinguish students who know concepts, misconceptions, and do not know concepts like Table 2.

Table 1. Categories of Confidence Levels Based on the CRI Scale

\begin{tabular}{lll}
\hline Category & Scale & Criteria \\
\hline Very Guessing & 0 & If in answering $100 \%$ guess \\
Almost Guessing & 1 & If in answering about the percentage of guesses $75 \%-99 \%$ \\
Not Sure & 2 & If in answering the question about the percentage of guesses $50 \%-74 \%$ \\
Confident & 3 & If in answering the question about the percentage of guesses is $25 \%-49 \%$ \\
Almost Very Sure & 4 & If in answering the question of guessing percentage of $1 \%-24 \%$ \\
Very sure & 5 & If in answering the percentage of guesses is $0 \%$
\end{tabular}

Source: (Gumilar, 2016)

Table 2. Category Level of Understanding of Concepts Based on CRI

\begin{tabular}{llll}
\hline Answer & CRI Value & Description & Indicator \\
\hline True & $>2,5$ & Mastering the Concept Well & $\begin{array}{l}\text { Explain the concept of momentum and impulse with the } \\
\text { right answers and a high level of confidence } \\
\text { Explain the concept of momentum and impulse with the } \\
\text { correct answer but low level of confidence }\end{array}$ \\
False & $>2,5$ & Don't Know Concept & $\begin{array}{l}\text { Errors explain the concepts of momentum and impulse } \\
\text { but the level of confidence in the answer is high } \\
\text { Error explains the concept of momentum and impulse } \\
\text { and the level of confidence in a low answer }\end{array}$ \\
\hline
\end{tabular}

Fourth, the percentage of data collected in this study was then calculated for each category using equation 1:

$$
P=\frac{f}{N} \times 100 \%
$$

Where :

$\mathrm{P}=$ group percentage figure

$\mathrm{f}=$ number of students in each group

$\mathrm{N}=$ number of individuals (total number of students who were subject to research
Finally, was calculating the average percentage of students' levels of misconception

\section{Result and Discussion}

Based on research that has been done in three schools namely PSHS Balung, Jember, and Pakusari. The number of students who are the subjects of research at PSHS Balung is 35 students, PSHS Jember is 35 students 
and PSHS Pakusari is 36 students. The class was chosen based on consideration between the researcher and the subject teacher concerned.
The number of students in PSHS Jember Regency Class $\mathrm{X}$ who experience misconceptions in each subchapter material momentum and impulses through the CR-integrated R-MV approach is as follows:

Table 3. Misconceptions of Class X Students at PSHS Balung

\begin{tabular}{llll}
\hline $\begin{array}{l}\text { Number } \\
\text { Problem }\end{array}$ & Sub-chapter Material & $\begin{array}{l}\text { Percentage of R-M } \\
\text { Misconception Students }\end{array}$ & $\begin{array}{l}\text { Percentage of R-V } \\
\text { Misconception Students }\end{array}$ \\
\hline 1 & Momentum & $0.00 \%$ & $0.00 \%$ \\
2 & Impulse & $14.29 \%$ & $42.86 \%$ \\
3 & Relationship between Momentum and Impulse & $54.29 \%$ & $31.43 \%$ \\
4 & Law of Conservation of Momentum & $17.14 \%$ & $14.29 \%$ \\
5 & Collision & $11.43 \%$ & $34.29 \%$ \\
Average & & $19.43 \%$ & $24.57 \%$ \\
\hline
\end{tabular}

Based on table 3 it can be seen that the average level of misconceptions of class $\mathrm{X}$ students of Natural Sciences in PSHS Balung on the material momentum and impulses through the mathematical representation approach of $19.43 \%$. While the average level of students' misconceptions of class $X$ Natural Sciences in PSHS Balung on the material of momentum and impulses through the verbal representation approach was $24.57 \%$. The causes of students' misconceptions are the ability to receive lessons in multi-representation from the students themselves, which is still lacking, causing students to experience misconceptions, from the way the teacher teaches material that has not yet been multirepresentation involving mathematical representations, pictures, graphics and verbal, so that students do not understand the material well and experience it misconceptions, the level of student confidence from the answers that students have chosen can also cause misconceptions.

Table 4. Misconceptions of Class X Students at PSHS Jember

\begin{tabular}{|c|c|c|c|}
\hline $\begin{array}{l}\text { Number } \\
\text { Problem }\end{array}$ & Sub-chapter Material & $\begin{array}{l}\text { Percentage of R-M } \\
\text { Misconception Students }\end{array}$ & $\begin{array}{l}\text { Percentage of R-V } \\
\text { Misconception Students }\end{array}$ \\
\hline 2 & Impulse & $0.00 \%$ & $17.14 \%$ \\
\hline 4 & Law of Conservation of Momentum & $20.00 \%$ & $37.14 \%$ \\
\hline 5 & Collision & $5.71 \%$ & $91.43 \%$ \\
\hline Average & & $8.00 \%$ & $53.14 \%$ \\
\hline
\end{tabular}

Based on table 4 above, it can be seen that the average level of students' misconceptions of Class $X$ Natural Sciences in PSHS Balung on the material of momentum and impulses through the mathematical representation approach is $8.00 \%$. While the average level of students' misconceptions of class X Natural Sciences in PSHS Balung on the material momentum and impulses through the verbal representation approach was $53.14 \%$.

The causes of students' misconceptions are the ability to receive lessons in multi-representation from the students themselves, which is still lacking, causing students to experience misconceptions, from the way the teacher teaches material that has not yet been multirepresentation involving mathematical representations, pictures, graphics and verbal, so that students do not understand the material well and experience it misconceptions, the level of student confidence from the answers that students have chosen can also lead to misconceptions (Nurulwati, 2014, Mursadam, 2017, Busyairi, 2020, Lestari, 2015).

Table 5. Misconceptions of Class X Students at Pakusari High School

\begin{tabular}{llll}
\hline $\begin{array}{l}\text { Number } \\
\text { Problem }\end{array}$ & \multirow{2}{*}{ Sub-chapter Material } & $\begin{array}{l}\text { Percentage of R-M } \\
\text { Misconception Students }\end{array}$ & $\begin{array}{l}\text { Percentage of R-V } \\
\text { Misconception Students }\end{array}$ \\
\hline 1 & Momentum & $33.33 \%$ & $2.78 \%$ \\
2 & Impulse & $38.89 \%$ & $2.78 \%$ \\
3 & Relationship between Momentum and Impulse & $72.22 \%$ & $77.78 \%$ \\
4 & Law of Conservation of Momentum & $5.56 \%$ & $22.22 \%$ \\
5 & Collision & $13.89 \%$ & $0.00 \%$ \\
Average & & $32.78 \%$ & $21.11 \%$ \\
\hline
\end{tabular}


Based on table 5 above, it can be seen that the average level of students' misconceptions of class $X$ Natural Sciences in PSHS Balung on the material of momentum and impulses through the mathematical representation approach is $32.78 \%$. While the average level of students' misconceptions of class X Natural Sciences in PSHS Balung on the material momentum and impulses through the verbal representation approach of $21.11 \%$.

The causes of students' misconceptions are the ability to receive lessons in multi-representation from the students themselves, which is still lacking, causing students to experience misconceptions, from the way the teacher teaches material that has not yet been multirepresentation involving mathematical representations, pictures, graphics and verbal so that students do not understand the material well and experience its misconceptions, the level of student confidence from the answers that students have chosen can also lead to misconceptions (Fakhruddin, 2012).

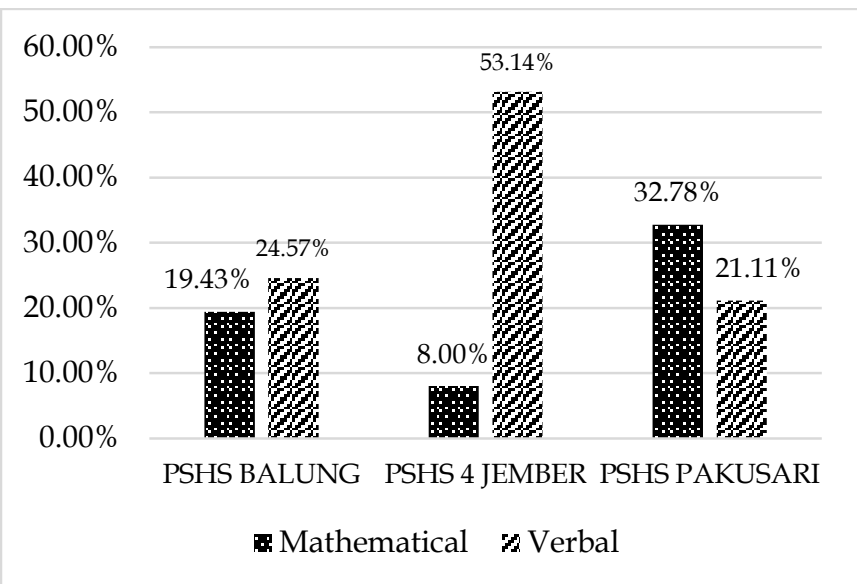

Figure 1. Graph of Percentage of Student Misconceptions on Momentum and Impulse Material through CRI Integrated RMV Approach in Class X PSHS Jember district.

Based on the average graph of the percentage of students 'misconceptions in the three PSHS of Jember Regency class $X$ in the material of momentum and impulses through the CR-integrated R-MV approach, the level of students' misconceptions in the mathematical representation in PSHS 4 Jember is smaller than other PSHS ie with a large percentage of $8.00 \%$. The highest level of students' misconceptions on mathematical representation is PSHS Pakusari with a large percentage of $32.78 \%$. While the level of students' misconceptions on verbal representation in PSHS Pakusari is smaller than the other two PSHS, with a large percentage of $21.11 \%$. The highest level of students' misconceptions on verbal representation was PSHS 4 Jember with a large percentage of $53.14 \%$. The average percentage of students' misconceptions of grade X PSA in Jember in the material momentum and impulses through the CRI integrated mathematical representation approach is $20.07 \%$. While the average percentage of students' misconceptions of class X PSHS in Jember in the material momentum and impulses through CRI integrated verbal representation approach of $32.94 \%$. The cause of multi representation misconceptions involves mathematical representations, pictures, graphics, and verbal, namely how to teach teachers who do not teach how to work on questions in multi representation. In addition, students experience misconceptions also because their physical knowledge is still fragmented so that students have difficulty in representing mathematical representations, graphic and verbal images (Wind, et.al., 2017, Doyan, 2018).

Based on the misconceptions that occur in students, to minimize student misconceptions, teachers should choose appropriate and appropriate learning methods based on the material to be taught. In addition, teachers should provide evaluation questions that can measure or identify whether students do not understand the concept or experience misconceptions about the material being taught (Maison, 2019).

\section{Conclusion}

Based on the results of the discussion that has been described, there are 2 conclusions. The percentage of students' misconceptions in PSHS class X of Jember Regency on the material of momentum and impulses through the CR-integrated R-MV approach is the mathematical representation of $20.07 \%$ and verbal representations of $32.94 \%$. The causes of students' misconceptions are the ability to receive lessons in multirepresentation from the students themselves, which is still lacking, causing students to experience misconceptions, from the way the teacher teaches material that has not yet been multi-representation involving mathematical representations, pictures, graphics and verbal so that students do not understand the material well and experience its misconceptions, the level of student confidence from the answers that students have chosen can also cause misconceptions. Based on research conducted in three PSHS in Jember Regency, it is known that a large percentage of misconceptions occur in students. With this result, the researcher hopes that there will be other researchers who can apply multi representative learning to reduce the occurrence of misconceptions in students in learning physics, especially in the concept of momentum and impulse. 


\section{References}

Angin, S.L., Sutopo., \& Parno. (2017). Pemahaman Mahasiswa tentang Multirepresentasi Konsep Percepatan. JRKPF UAD. 4(2): 48-53.

A' yun, Q., Harjito., \& Nuswowati, M. (2018). Analisi Miskonsepsi Siswa Menggnakan Tes Diagnostic Multiple Choice Berbantuan CRI (Certainly of Response Index). Jurnal Inovasi Pendidikan Kimia. 12(1): 2108-2117.

Bektiarso, S. (2000). Pentingnya Konsepsi Awal Dalam Pembelajaran Fisika. Jurnal Saintifika.1(1), doi: $\underline{10.29103 / \text { relativitas.v1i1.1195 }}$

Busyairi, A., \& Zuhdi, M., (2020). Profil Miskonsepsi Mahasiswa Calon Guru Fisika Ditinjau Dari Berbagai Representasi Pada Materi Gerak Lurus Dan Gerak Parabola. Jurnal Pendidikan Fisika dan Teknologi, 6(1), 90-98, http://dx.doi.org/10.29303/jpft.v6i1.1683

Doyan, A., Taufik, M., \& Anjani, R., (2018). Pengaruh Pendekatan Multi Representasi terhadap Hasil Belajar Fisika Ditinjau dari Motivasi Belajar Peserta Didik. Jurnal Penelitian Pendidikan IPA, 4(1), 35-45,doi: 10.29303/jppipa.v4i1.99

Fadli, M., Pasaribu, M., \& Darsikin. (2016). Analisis Miskonsepsi Mahasiswa Program Studi Pendidikan Fisika menggunakan Certainty Of Response Index (CRI) pada Konsep Gaya. Jurnal Pendidikan Fisika Tadulako. 4 (4): 30.

Fakhruddin., Azizahwati., \& Rahmi, Y. (2012). Analisis Penyebab Miskonsepsi Siswa pada Pelajaran Fisika di Kelas XII SMA/MA Kota Duri. Jurnal Pendidikan Matematika. 3(1): 87-98. doi: http://dx.doi.org/10.36709/jpm.v3i1.1988

Gumilar, S. (2016). Analisis Miskonsepsi Konsep Gaya Menggunakan Certainty of Response Index (CRI). GARVITY. Vol. 2 (1): 62. doi: http://dx.doi.org/10.30870/gravity.v2i1.924

Hidayat, A. (2017). Identifikasi Miskonsepsi Konsep Momentum, Impuls dan Tumbukan dengan Tes Diagnostik Empat Tahap pada Siswa SMA Kelas XII. Skripsi. Bandung: Program Studi Pendidikan Fisika Jurusan Pendidikan MIPA Fakultas Keguruan dan Ilmu Pendidikan Universitas Jember.

Lestari, P.S.A., Rahayu, S., \& Hikmawati. (2015). Profil Miskonsepsi Siswa Kelas X Smkn 4 Mataram Pada Materi Pokok Suhu, Kalor, Dan Perpindahan Kalor, Jurnal Pendidikan Fisika dan Teknologi, 1(3), 146-153. doi: http://dx.doi.org/10.29303/jpft.v1i3.251

Maison, Lestari, N., Widaningtyas, A. (2020). Identifikasi Miskonsepsi Siswa pada Materi Usaha dan Energi. Jurnal Penelitian Pendidikan IPA
(JPPIPA). 6(1). pp. 32-39, doi : 10.29303/jppipa.v6i1.314

Mahardika, I.K. (2016). Penggunaan Pendekatan Multirepresentasi Dengan Setting Quantum Teaching Dalam Pembelajaran Gerak Melingkar Dan Dampaknya Terhadap Pemahamankonsep Mahasiswa Calon Guru Fisika. Seminar Nasional Pendidikan Fisika 2016. 1: 21 Mei 2016, 546.

Mursadam., Wildan, \& Ramdani, A., (2017). Pengembangan Instrumen Miskonsepsi Kimia Pada Konsep Struktur Atom, Jurnal Penelitian Pendidikan IPA, 3(2), 16-25. doi: https:// doi.org/10.29303/ippipa.v3i2.87

Nurulwati, Veloo, A., \& Ali, R.M. (2014). Suatu Tinjauan Tentang Jenis-Jenis dan Penyebab Miskonsepsi Fisika. Jurnal Pendidikan Sains Indonesia. 2(1): 8795.

Prain, V., \& Waldrip, B.G. (2008). An Exploratory Study of Teachers Perspectives About Using MultiModal Representations of Concepts to Enhance Science Learning. Canadian Journal of Science, Mathematics and Technology Education. 8(1). doi: https://doi.org/10.1080/14926150802152152

Sanjaya, W. (2013). Penelitian Pendidikan: Jenis, Metode dan Prosedur. Jakarta: Kencana Prenada Media Group.

Suparno, P. (2013). Miskonsepsi \& Perubahan Konsep dalam Pendidikan Fisika. Jakarta: PT Grasindo.

Trianto. (2013). Mendesain Model Pembelajaran InovatifProgresif: Konsep, Landasan, dan Implementasinya pada Kurikulum Tingkat Satuan Pendidikan (KTSP). Jakarta: Kencana Prenada Media Grup. 